\title{
Hydrocephaly-tall stature-joint laxity syndrome
}

INSERM

\section{Source}

INSERM. (1999). Orphanet: an online rare disease and orphan drug data base.

Hydrocephaly-tall stature-joint laxity syndrome. ORPHA:2181

Hydrocephaly-tall stature-joint laxity syndrome is a multiple congenital anomalies

syndrome described in two sisters and characterized by the presence of hydrocephalus (onset in infancy), tall stature, joint laxity, and thoracolumbar kyphosis. There have been no further descriptions in the literature since 1989. 